\title{
EFEKTIFITAS SOSIALISASI MAL OLEH KONSELOR ASI SEBAGAI SALAH SATU UPAYA PENCEGAHAN UNMEET NEED KB
}

\author{
Luluk Rosida*, Nidatul Khofiyah
}

\author{
*Program Studi Kebidanan, Universitas 'Aisyiyah Yogyakarta, rosidalulu@gmail.com \\ Program Studi Kebidanan, Universitas ‘Aisyiyah Yogyakarta, nidatulkhofiyah@unisayogya.ac.id
}

\begin{abstract}
INFO ARTIKEL
\section{Riwayat Artikel:}

Diterima: 15-11-2018

Disetujui: 22-12-2018

\section{Kata Kunci:}

Effectiveness

ABSTRAK

Abstrak : Metode Amenore laktakasi (MAL) merupakan alternatif yang dapat digunakan oleh ibu yang mengalami unmet need KB karena menyusui menyebabkan penundaan pemulihan kesuburan setelah persalinan. Tujuan penelitian ini adalah untuk mengetahui efektifitas sosialisasi MAL oleh konselor ASI terhadap upaya penurunan angka unmeet need di Kota Yogyakarta. Penelitian quasi ini menggunakan desain Non-Equivalent Control Group Sampel dalam penelitian ini adalah ibu yang baru melahirkan di Puskesmas rawat inap di Kota Yogayakarta. Analisis bivariat menggunakan uji man whtney. Hasil penelitian menunjukkan terdapat perbedaan kembalinya menstruasi pada ibu nifas yang diberikan sosialisasi MAL oleh konselor ASI dengan ibu nifas yang tidak diberikan sosialisasi MAL.
\end{abstract}

Unmeet Need

Contraception

LAM

Menstruation

\begin{abstract}
The purpose of this study was to determine the effectiveness of the socialization of $L A M$ by a breastfeeding counselor to efforts to reduce unmeet need in Yogyakarta. This quasi study uses the design of Non-Equivalent Control Group. Women who are exclusively breastfeeding will in principle get longer menstrual initiation than those who do not exclusively breastfeed their babies. The sample in this study were mothers who had just given birth. Bivariate analysis using the man whtney test. The results showed that there were differences in the return of menstruation in postpartum mothers who were given $L A M$ socialization by ASI counselors with postpartum mothers who were not given LAM socialization.
\end{abstract}

\section{A. LATAR BELAKANG}

Masalah kependudukan berkembang menjadi masalah dunia atau globalkarena dapat merupakan faktor-faktor gangguan sosial ekonomi dan sosial politik. Inilah sebabnya dunia internasional menaruh perhatian terhadap program KB sebagai bagian dari kebijakan kependudukan dunia dan mengharapkan $\mathrm{KB}$ mendapatkan prioritas dalam pengupayakan peningkatan kesejahteraan dalam pembangunan nasional.

Salah satu masalah dalam pengelolaan program KB yaitu masih tingginya angka UnmetNeed $\mathrm{KB}$, yaitu jumlah Pasangan Usia Subur (PUS) yang ingin menunda kehamilan atau tidak menginginkan tambahan anak tetapi tidak ber KB. Di Indonesia angka unmet need mencapai 11 persen dengan 4 persen untuk penjarangan dan 7 persen untuk pembatasan. Angka ini meningkat dibanding dari hasil survey sebelumnya yaitu 8,6 persen. Presentase wanita kawin yang memerlukan pelayanan $\mathrm{KB}$ saat ini di Indonesia sekitar 73\% dimana 85\% diantaranya telah terpenuhi. Jika semua kebutuhan pelayanan KB terpenuhi maka prevalensi kontrasepsi dapat ditingkatkan dari 62\% menjadi 73\%. Dari laporan SDKI 2012, data ini tidak berubah. Sebanyak $88 \%$ wanita berstatus kawin memiliki kebutuhan pelayanan KB yang terpenuhi hampir sama dengan keadaan pada tahun 2007 (87 \%), artinya presentase akseptor baru tidak meningkat secara signifikan hanya $1 \%$ saja (Rismawati, 2012).

Angka Unmet need (kelompok umur yang membutuhkan pelayanan KB tapi tidak mendapatkannya) tahun 1991-2012 cenderung menurun dari 12,7\% menjadi $8,5 \%$. Namun, dalam 5 tahun terakhir dari tahun 20072012 angka masih tinggi dan hanya mengalami penurunan 0,6 \% dimana angka ini sempat meningkat pada tahun 2007 sedangkan target RPJMN 2014 sebesar 6,5\% dan target $M D G$ s 2015 sebesar 5\% (SDKI,2012). Angka unmet need di daerah Provinsi Yogyakarta dimana Kulon Progo sebesar 7,01 \%, Bantul sebesar 5,95 \%, Gunung Kidul sebesar 8,51 \%, Sleman sebesar 9,42 \%, dan Kota Yogyakarta sebesar 11,46 \% (BKKBN, 2016).

Berdasarkan data tersebut diharapkan pelayanan Keluarga Berencana (KB) pasca persalinan menjadi salah satu program strategis untuk menurunkan kehamilan yang tidak diinginkan akibat unmet need. Penelitian menunjukkan bahwa pemberian ASI dapat mempengaruhi lamanya amenorea dan frekuensi ovulasi. Tingginya frekuensi pemberian ASI, lamanya setiap pemberian, dan kurangnya frekuensi pemberian makanan tambahan akan menurunkan kemungkinan terjadinya ovulasi dan kembalinya siklus menstruasi (Kemenkes RI, 2010). 
Keberadaan konselor ASI sebenarnya dapat ikut juga membantu pelaksanaan sosialisai MAL pada masa transisi sehabis melahirkan sehingga dapat mengurangi angka unmeet need hal ini sangat penting karena MAL berguna sebagai kontrasepsi transisi dimana metode ini menjadi perantara untuk KB metode modern lainnya. Metode ini memberikan waktu 2 kali lebih lama untuk pasutri memutuskan menggunakan KB lanjutan. Pentingnya waktu transisikarena kesuburan dapat kembali segera pascapersalinan. Pada wanita yang menyusui tidak untuk MAL dapat berovulasi bahkan sebelum mendapat menstruasi. Sekitar 5-10 \% wanita hamil lagi setelah 1 tahun postpartum (Octarianingsih, 2016).

Perumusan Masalah dalam penelitian ini adalah : Berdasarkan latar belakang yang sudah dipaparkan maka rumusan masalah dalam penelitian ini adalah "Bagaimana efektifitas konselor ASI dalam sosialisasi MAL terhadap upaya penurunan angka unmeet need di Kota Yogyakarta?”

\section{B. METODE PENELITIAN}

Jenis penelitian ini adalah Quasi Experiment, desain yang digunakan dalam penelitian ini adalah NonEquivalent Control Group Design.Penelitian ini membandingkan kembalinya menstruasi pada ibu nifas dengan ASI eksklusif yang diberikan sosialisasi MAL dengan ibu nifas yang tidak diberikan sosialisasi MAL. Populasi dalam penelitian ini adalah ibu yang baru melahirkan di Puskesmas Rawat Inap Kota Yogyakarta. Pengambilan sampel menggunakan teknik accidental sampling. Pada penelitian ini peneliti akan mengambil sampel sebanyak 50 responden yaitu 25 untuk kelompok perlakuan dan 25 untuk kelompok kontrol yang akan dibedakan waktu kembali menstruasi. Pengumpulan data dilakukandengan cara membagikan kuesioner kepada ibu responden guna mengetahui karakteristik responden penelitian. Kuesioner dikumpulkan pada saat itu juga. Kemudian responden diberikan sosialisasi tentang MAL oleh konselor ASI yang akan dilakukan follow up setiap bulan untuk diukur kapan kembalinya menstruasi untuk pertama kali setelah persalinan. Untuk mencari hubungan antar variabel digunakan uji man whitneydengan $C I$ 95\%.

\section{HASIL DAN PEMBAHASAN}

\section{Karakteristik Responden}

Identifikasi responden berdasarkan paritas, umur ibu, pendidikan dan pekerjaan disajikan pada tabel berikut ini:

\section{TABEL 1}

Distribusi Frekuensi Karakteristik Responden Berdasarkan Umur Ibu, Umur Balita, Riwayat Persalinan Lalu dan

\begin{tabular}{lllll}
\multicolumn{5}{c}{ Penolong Persalinan } \\
\hline Karakteristik & \multicolumn{2}{c}{ Kelompok } & \multicolumn{2}{l}{ Kelompok } \\
& \multicolumn{2}{c}{ Kontrol } & \multicolumn{2}{c}{ Eksperimen } \\
& $\mathrm{f}$ & $\%$ & $\mathrm{f}$ & $\%$ \\
\hline Umur Ibu & & & & \\
$<$ 20 tahun & 1 & 3,3 & 3 & 10 \\
20-30 tahun & 23 & 76,7 & 19 & 63,3 \\
>35 tahun & 6 & 20,0 & 8 & 26,7 \\
Umur balita & & & & \\
7 bulan & 20 & 66,7 & 3 & 10,0 \\
8 bulan & 5 & 16,7 & 14 & 46,7 \\
$\quad$ bulan & 5 & 16,7 & 8 & 26,7 \\
10 bulan & 0 & 0 & 2 & 6,7 \\
12 bulan & 0 & 0 & 3 & 10,0 \\
Riwayat & & & & \\
persalinan & & & & \\
Normal & 25 & 83,3 & 25 & 83,3 \\
SC & 5 & 16,7 & 5 & 16,7 \\
Penolong & & & & \\
persalinan & & & & \\
Bidan & 14 & 46,7 & 23 & 76,7 \\
Dokter & 6 & 53,3 & 7 & 23,3 \\
Swasta & 7 & 23,3 & 10 & 33,3 \\
\hline
\end{tabular}

Dari tabel 1 dapat diketahui bahwa karakteristik kedua kelompok meliputi : Umur ibu pada kedua kelompok mayoritas berumur 20-30 tahun dimana pada kelompok intervensi sebanyak 63,3 \% (19 responden) dan pada kelompok kontrol sebanyak 76,7\% (23 responden), umur balita pada kelompok intervensi mayoritas umur 7 bulan $20(66,7 \%)$ dan pada kelompok kontrol umur bayi mayoritas berumur 8 bulan sebanyak 14 (46,7\%), Riwayat persalinan lalu pada kedua kelompok mayoritas melahirkan normal yaitu sebanyak 25 responden (83,3\%). Sedangkan pada penolong persalinan kelompok intervensi mayoritas adalah bidan yaitu sebanyak 14 responden (46,7\%) pada kelompok kontrol dan 23 responden $(76,7 \%)$ pada kelompok intervensi.

\section{TABEL 2}

Distribusi Frekuensi Karakteristik Responden Berdasarkan Pekerjaan dan Tingkat Pendidikan

\begin{tabular}{|c|c|c|c|c|}
\hline \multirow[t]{2}{*}{ Karakteristik } & \multicolumn{2}{|c|}{$\begin{array}{l}\text { Kelompok } \\
\text { Kontrol }\end{array}$} & \multicolumn{2}{|c|}{$\begin{array}{l}\text { Kelompok } \\
\text { Eksperimen }\end{array}$} \\
\hline & $\mathrm{f}$ & $\%$ & $\mathrm{f}$ & $\%$ \\
\hline \multicolumn{5}{|l|}{ Pekerjaan } \\
\hline IRT & 19 & 63,3 & 18 & 60,0 \\
\hline Karyawan Swasta & 4 & 13,3 & o & $\mathrm{O}$ \\
\hline Pedagang & $\mathrm{O}$ & $\mathrm{O}$ & 1 & 3,3 \\
\hline Petani & $\mathrm{O}$ & $\mathrm{O}$ & 1 & 3,3 \\
\hline Swasta & 7 & 23,3 & 10 & 33,3 \\
\hline \multicolumn{5}{|c|}{ Tingkat pendidikan } \\
\hline SD & $\mathrm{O}$ & $\mathrm{O}$ & 1 & 3,3 \\
\hline SMP & 1 & 3,3 & 5 & 16,7 \\
\hline SMA & 21 & 53,3 & 16 & 53,3 \\
\hline PT & 8 & 16,3 & 8 & 26,7 \\
\hline
\end{tabular}

Dari tabel 2 dapat diketahui bahwa karkteristik pekerjaan pada kedua kelompok adalah IRT yaitu sebanyak 19 responden ( 63,3\%) pada kelompok control dan sebanyak 18 responden $(60,0 \%)$ pada kelompok intervensi. Tingkat pendidikan pada kedua kelompok 
mayoritas berpendidikan SMA 21 (53,3\%) pada kelompok kontrol dan 16 responden (53,3\%) pada kelompok intervensi.

\section{Analisis Univariat}

1) Kelompok Intervensi

Tabel 3 Gambaran kembalinya menstruasi pada kelompok yang di berikan konseling oleh konselor ASI.

TABEL 3

Gambaran Kembalinya Menstruasi Pada Kelompok yang Diberikan Konseling Oleh Konselor ASI

\begin{tabular}{cll}
\hline \multirow{2}{*}{ Menstruasi Kembali } & Intervensi & \\
& f & \% \\
\hline a. $<6$ bulan & 14 & 46,7 \\
b. $>6$ bulan & 16 & 53,3 \\
\hline Total & $\mathbf{3 0}$ & $\mathbf{1 0 0}$ \\
\hline
\end{tabular}

Berdasarkan tabel 3 Pada kelompok yang diberikan konseling oleh konselor ASI mayoritas mengalami kembali menstruasi setelah 6 bulan yaitu sebanyak 16 responden $(53,3 \%)$.

\section{2) Kelompok Kontrol}

Tabel 4 Gambaran kembalinya menstruasi pada kelompok yang tidak di berikan konseling oleh konselor ASI

TABEL 4

Gambaran Kembalinya Menstruasi Pada Kelompok yang Tidak Diberikan Konseling Oleh Konselor ASI

\begin{tabular}{cll}
\multicolumn{3}{c}{ Kontrol } \\
Menstruasi Kembali & f & \% \\
\hline a. $<6$ bulan & 25 & 83,3 \\
b. $>$ 6 bulan & 5 & 16,7 \\
\hline Total & $\mathbf{3 0}$ & $\mathbf{1 0 0}$ \\
\hline
\end{tabular}

\section{Analisis Bivariat}

Tabel 5 Perbedaan waktu kembalinya menstruasi pada kelompok kontrol maupun intervensi

TABEL 5

Perbandingan Waktu Kembalinya Menstruasi Pada Kelompok Kontrol dan Kelompok Eksperimen

$\begin{array}{llll} & & \text { Mean } & p-\text { value } \\ \text { Kelompok } & \mathrm{N} & \text { Rank } & \end{array}$

\begin{tabular}{|c|c|c|c|}
\hline $\begin{array}{l}\text { Diberi konseling oleh } \\
\text { Konselor ASI } \\
\text { Tidak diberi konseling } \\
\text { oleh konselor ASI }\end{array}$ & $\begin{array}{l}30 \\
30\end{array}$ & $\begin{array}{l}25,00 \\
36,00\end{array}$ & 0,003 \\
\hline
\end{tabular}

Berdasarkan tabel 5 hasil analisis pada kelompok intervensi dinyatakan bahwa nilai Signifikansi: 0,003 maka Ho di tolak Ha diterima artinya bahwa konselor ASi efektif dalam mensosialisasikan metode MAL dalam rangka mencegah angka unmeet need $\mathrm{KB}$.

\section{PEMBAHASAN}

Berdasarkan hasil penelitian ini didapatkan kelompok yang mendapatkan konseling tentang ASI Ekslusif lebih banyak yang mengalami kembali menstruasi setelah 6 bulan yaitu sebesar 53,3\% hal ini sesuai dengan Penelitian
N. Leach yang meneliti 80 ribu ibu menyusui menunjukan bahwa ibu-ibu yang memenuhi semua kebutuhan nutrisi bayinya selama enam bulan pertama dari ASI dan terus dari ASI, meski hanya sebagian untuk bulan-bulan berikutnya serta membiarkan bayinya menghisap payudaranya, cenderung tidak berovulasi sampai 12 bulan setelah melahirkan. R short mengatakan di Afrika, kesinambungan memberi ASI, meski hanya sebentar di siang hari dan malam hari, sampai anak berusia sekitar lima tahun, dapat menjarangkan kehamilan secara alami dengan selang waktu sekitar 4 tahun. Jika makanan padat sudah diberikan pada bayi yang baru berusia beberapa bulan atau bila ibu cemas dengan persediaan ASI nya, atau air susu yang dirpoduksi berkurang karena alasan tertentu, maka ovulasi bisa segera kembali (Billings, 2008).

Seiring dengan penurunan frekuensi dan durasi menyusui dan terutama dengan dipekenalkannya makanan selain ASI, efek pada sumbu hipotalamushipofisis-ovarium melemah dan aktivitas ovarium mulai kembali. Dengan demikian, pola pemberian makan bayi dan waktu pascapartum memengaruhi durasi inferilitas laktasional. Pulihnya menstruasi mungkin didahului oleh perkembangan folikel disertai produksi estrogen yang memadai untuk merangsang pertumbuhan endometrium (dan penurunannya saat kadar estrogen turun). Dengan demikian, awal menstruasi merupakan tanda akan pulihnya kesuburan (Glasier, 2006).

Berdasarkan hasil observasi ovulasi pertama pada wanita yang tidak menyusui secara rata-rata adalah 45 hari pascapartum, maka wanita yang memberi susu formula pada bayinya dianjurkan untuk mulai menggunakan kontrasepsi sejak 4 minggu setelah melahirkan. Di Inggris, pemeriksaan post natal rutin oleh dokter umum secara klasik dilakukan pada 6 minggu pascapartum. Tidak semua rumah sakit menyediakan alat kontrasepsi bagi wanita yang dipulangkan setelah melahirkan tetapi untungnya aktivitas seksual jarang atau tidak terjadi pada minggu-minggu awal masa nifas sehingga konsepsi dini sangat jarang dijumpai. Sebagaimana yang telah dibahas diatas, menyusui dapat menunda pemulihan kesuburan dan dalam teori pemakaian kontrasepsi dapat ditunda lebih lama. Namun, pada praktiknya, wanita yang menyusui biasanya juga diberi anjuran untuk mulai menggunakan kontrasepsi pada 4 minggu setelah melahirkan, walaupun anjuran ini memperlihatkan ketidaktahuan mengenai fisiologi reproduksi, namun juga bersifat plagmatis karena banyak wanita di negara maju memberi ASI hanya dalam waktu singkat dan cenderung memperkenalkan makanan tambahan secara dini. Bagi wanita, yang mengandalkan amenore laktasi sebagai kontrasepsi, maka mereka harus mengikuti aturan-aturan MAL (Glasier,2006).

Seiring dengan penurunan frekuensi dan durasi menyusui dan terutama dengan dipekenalkannya makanan selain ASI, efek pada sumbu hipotalamushipofisis-ovarium melemah dan aktivitas ovarium mulai 
kembali. Dengan demikian, pola pemberian makan bayi dan waktu pascapartum memengaruhi durasi inferilitas laktasional. Pulihnya menstruasi mungkin didahului oleh perkembangan folikel disertai produksi estrogen yang memadai untuk merangsang pertumbuhan endometrium (dan penurunannya saat kadar estrogen turun). Dengan demikian, menstruasi merupakan tanda akan pulihnya kesuburan (Glasier, 2006)

Menurunnya kadar estrogen menimbulkan terangsangnya kelenjar pituitari bagian belakang untuk mengeluarkan produksi susu. Pada wanita yang menyusui bayinya, kadar prolaktin tetap tinggi dan pada permulaan rangsangan folikel dalam ovarium ditekan. Pada wanita yang tidak menyusui bayinya tingkat sirkulasi prolaktin menurun dalam 14-21 hari setelah persalinan, sehingga merangsang kelenjar bawah depan otak yang mengontrol ovarium ke arah permulaan pola produksi estrogen dan progesteron yang normal, pertumbuhan folikel, ovulasi dan menstruasi (Saleha, 2009).

Menstruasi yang didapat setelah melahirkan waktunya relatif, ada yang 1 tahun setelah melahirkan, 6 bulan setelah melahirkan dan ada yang 3 bulan setelah melahirkan. Cepat atau lambatnya untuk kembali lagi haid salah satunya dipengaruhi oleh hormon prolaktin dan progesteron. Prolaktin sendiri adalah hormon yang merangsang kelenjar susu memproduksi ASI. Jika ibu menyusui secara efektif, maka akan meningkatkan produksi prolaktin, dimana peningkatan hormon prolaktin ini dapat menekan hormon progesteron dan estrogen yang terlibat dalam terjadinya haid. Artinya, jika ibu menyusui bayi secara efektif dan kontinyu tanpa diselang oleh susu formula, maka untuk terjadinya kembali haid akan lebih lama, bisa sampai satu tahun bahkan ada yang dua tahun. Ini yang dinamakan kontrasepsi alami (Irmawati, 2014).

Peran konselor ASI dalam memberikan konseling cara pemberian ASI yang tepat bisa membantu ibu ibu yang belum menenttukan pilihan KB secara permanen pada masa antara untuk dapat menunda kehamilannya dengan cara pemberian ASI yang tepat dtandai dengan salah satunya kembalinya menstruasi setelah 6 bulan pasca salin.

\section{KESIMPULAN}

Hasil analisis pada kelompok intervensi dinyatakan bahwa nilai Signifikansi: 0,003 maka Ho di tolak Ha diterima artinya bahwa konselor ASi efektif dalam mensosialisasikan metode MAL dalam rangka mencegah angka unmeet need $\mathrm{KB}$.

\section{UCAPAN TERIMAKASIH}

Terimakasih kepada Kemenristekdikti yang telah mendanai penelitian ini.

\section{DAFTAR RUJUKAN}

[1] Affandi, Biran, dkk. (2012). Buku Panduan Praktis Pelayanan Kontrasepsi, PT. Bina Pustaka Sarwono Prawirohardjo, Jakart

[2] Billings, Evelyn. (2008). Metode Ovulasi Billings, PT.Gramedia, Jakarta

[3] BKKBN. (2016) . Rapat Pengendalian Program Anggaran, D.I Yogyakarta

[4] Departemen Kesehatan R.I. (2010). Strategi nasional peningkatan pemberian ASI dan MPASI, Direktorat Bina Gizi Masyarakat dan UNICEF. Jakarta

[5] Endah, Purwaningsih. (2015). Hubungan Frekuensi Menyusui dengan Keberhasilan Metode MAL di Kelurahan Ringin Putih Karangdowo Klaten. Jurnal Involusi Kebidanan.

[6] Glaseir, Anna dan Ailsa Gebbie (2006). Keluarga Berencana dan Kesehatan Reproduksi, EGC, Jakarta

[7] Guyton \& Hall, J.E. (2008). Buku Ajar Fisiologi Kedokteran Edisi 1, EGC, Jakarta

[8] Indarwati, dkk. (2007). Perilaku Ibu Memanfaatkan Pelayanan Kesehatan Selama Hamil dan Penggunaan Kontrasepsi Selama Menyusui. Berita Kedokteran Masyarakat.

[9] Irmawati.(2014). Frekuensi menyusui dengan keberhasilan kontrasepsi Metode Amenorhea Laktasi (MAL) Di desa Leminggir Kecamatan Mojosari Mojokerto ,Laporan Penelitian

[10] KementerianKesehatan. (2010). KBP ada Periode Menyusui, Kajian Health Technology Assessment Indonesia, Jakarta

[11] Muryanta, Andang. (2012) . Amenore Laktasi Sebagai Metode BerKB Serta Urgensinya Terhadap PP 3 Tahun 2012.Artikel BKKBN

[12] Nursalam. (2008) .Konsep dan Penerapan Metode Penelitian Ilmu Keperawatan, Salemba Medika, Jakarta

[13] Notoatmodjo, Soekidjo. (2012) . Metodologi Penelitian, PT.Rineka Cipta, Jakarta

[14] Octarianigsih, Fonda. (2016). MetodeAmenoreLaktasi, dalamhttp://malahayati.ac.idwpcontentuploads201610M ATERI-3 1.pdf, diaksestanggal 18 Januari 2017

[15] Rismawati, Sariestya. (2012). Unmet Need: Tantangan Program Keluarga Berencana Dalam Menghadapi Ledakan Penduduk Tahun 2030. Artikel. Mahasiswa Megister Kebidanan Fakultas Kedokteran UNPAD Bandung.

[16] Roesli, Utami. (2009). Panduan Praktis Menyusui, Pustaka Bunda, Jakarta

[17] Saleha,Siti. (2009). Asuhan Kebidanan Pada Masa Nifas, Salemba Medika, Jakarta

[18] SDKI, 2012. Buletin Jendela Data dan Informasi Kesehatan, Kementerian Kesehatan RI 2013, Jakarta

[19] Speroff, L.,and Fritz, M.A., 2011. Clinical Gynegologic Endocrinology and Infertility Edisi 8, Lippincott Williams \& Wilkins, Philadelphia

[20] Uparmi. (2010).Pengaruh ASI Eksklusifterhadap Amenorrhea Laktasi di Indonesia. Tesis.Depok.UI

[21] Wiji, RizkiNatia. (2013).ASI Dan PanduanIbuMenyusui, NuhaMedika, Yogyakarta

[22] Willy, Andika. (2011). The Relationship Exclusive Breastfeeding With The Menstrual Cycle In BreastfeedingMothers (studies inpuskesmasbungkal, districtbungkal, ponorogo ). Nursing Jurnal Of STIKES Insan Cendekia Medika Jombang.

[23] Yuliarti, Nurheti. (2010).Keajaiban ASIMakananTerbaikUntukKesehatan, Kecerdasan, danKelincahan Si kecil, C.V Andi Offset, Yogyakarta 